\title{
Development Of Guided Inquiry Learning Model By Articulate Storyline Media On Elasticity Materials To Increase Student's Motivation And Learning Achievement
}

\author{
Mas'adah*, Wasis*, Tjipto Prastowo* \\ ${ }^{*}$ Postgraduate Study of Science Education, Postgraduate, State University of Surabaya, Indonesia \\ DOI: 10.29322/IJSRP.9.12.2019.p9648 \\ http://dx.doi.org/10.29322/IJSRP.9.12.2019.p9648
}

\begin{abstract}
The aim of this reasearch is development of guided inquiry learning model by articulate storyline media on elasticity materials to increase student's motivation and learning achievement.This research type is development research, researchers develop instrument that produce certain products that include syllabus, lesson plans, student activity sheets (student worksheets), student books, and knowledge learning test results. The subject of this research is the instructional guided inquiry learning model by articulate storyline media while the test subjects are 60 students divided into 2 classes, namely X MM 1 and X MM 2 at SMK Al-Amin Surabaya in Academic Year 2019/2020. This research development of guided inquiry learning model by articulate storyline media was carried out through two stages, namely the development phase of the learning instruments and the testing phase of the learning instrument. Based on the research results of the development phase and the trial phase II that has been carried out on 60 students of X-MM class of SMK Al-Amin Surabaya it can be concluded that: (a) Guided inquiry learning model by articulate storyline media on elasticity material consisting of syllabus, lesson plans, student worksheets, student books, and knowledge test sheets have met the validity requirements of a learning instruments. (b) Guided inquiry learning model by articulate storyline media on elasticity material that has been developed otherwise practical. This is seen from the implementation of learning that gets an average of $>3.00$, positive student activity increases at the next meeting, and obstacles that occur during the learning process can find alternative solutions so that learning objectives are still achieved. (c) The instructional guided inquiry learning model by articulate storyline media on elasticity material is declared effective. This is observed from the increase in student learning achievement after learning using the developed learning instrument, in addition to that student motivation also increases. Based on the conclusions above, it can be concluded that in general the development of guided inquiry learning model by articulate storyline media on elasticity material to increase student's motivation and learning achievement.
\end{abstract}

Index Terms- Guided Inquiry Learning Model, Articulate Storyline Media, Elasticity Materials, Student's Motivation, Learning Achivement

\section{INTRODUCTION}

Education is a means and vehicle that plays an important role in producing competent human resources because it is in education that individuals are processed into human beings who have competitiveness. In Perpu No.20 of 2003 it is said that national education aims to develop the potential of students to become human beings who believe in and fear God Almighty, have noble, healthy, knowledgeable, capable, creative, independent, and become democratic citizens and citizens to be responsible. To achieve these educational goals, the government established educational institutions ranging from elementary to tertiary levels to bridge the community in learning. However, of the many schools established by the government, there is one educational institution that is more focused on skills, namely Vocational High Schools (SMK). Specifically, it can be explained the purpose of organizing the Vocational High School which is directed to prepare students to have an understanding of the skills of work with the quality of graduates to be able to meet the demands of the professional world of work and industry. However, in reality, the quality of vocational education is still not running optimally, so that it falls into the low category. The cause of SMK graduates who are unemployed is because these graduates are not fit for employment. One of the factors of the high unemployment rate of SMK graduates is that their competence is less accepted in the employment industry. Furthermore, the Open Unemployment Rate (TPT) of SMK graduates was 8.92\% based on data from the Central Statistics Agency (BPS) as of 2018. It can be concluded that SMK graduates still did not meet the criteria desired by the industrial world. The quality of vocational education must be improved to be able to produce competent graduates and be able to be absorbed by the industrial world.

Based on the results of the preliminary study of researchers at Al-Amin Vocational School Surabaya in class X-MM and the results of the researchers interview with one of the physics teachers at the school, the following findings were obtained: teachers at the school 
generally still use learning patterns that are teacher-centered, where the role the teacher still dominates the process of learning activities. One reason for this is the lack of teachers who carry out comprehensive learning planning activities. What is meant by comprehensive is developing and developing learning tools that are by the objectives and competencies of learning to be achieved. During this time the efforts made by the teacher are to apply the learning method through discussion and question and answer in class. Students are less actively involved in searching and finding information themselves. Practical activities are carried out if the conditions and time allow. Learning has the opportunity to create learning patterns that are monotonous and not by the characteristics of the material so that students tend to be bored, sleepy, and do other activities in the classroom. This certainly has an impact on the low learning achievement and the level of student understanding. Even the material elasticity that is quite essential in daily life also gets an average low learning outcome. The low learning achievement can be seen in the data shown by the physics teacher at Al-Amin Vocational School that the average daily test scores of students only reach 68.50. This means that many students get incomplete grades when doing daily tests. In addition to the data and the results of teacher interviews, researchers also conducted interviews with class X students. Based on the results of researcher's interviews with existing students, it was found that class X students majoring in multimedia in physics subjects complained a lot because they felt physics lessons were less supportive of vocational they took, namely multimedia majors. This shows the lack of student motivation to learn because students are more likely to like things based on multimedia.

The selection of learning models must be by the objectives of the curriculum, where learning in the 2013 curriculum at all levels uses a scientific approach. The scientific approach includes five learning experiences, namely observing, questioning, gathering information/experimenting, reasoning/associating, communicating. Inquiry involves students in activities and skills by focusing on the active search for knowledge and understanding [1]. Inquiry also can improve student's mastery of concepts and science process skills in learning activities. Guided inquiry is one of the levels in inquiry learning model that can be applied in the learning process at Vocational Schools because it matches the characteristics of students, where the intellectual development of middle-level students is still in the formal operational level which means that children can think logically and theoretically based on proportions. Another consideration for the use of guided inquiry is that the implementation of inquiry learning without guidance will confuse students so that guided inquiry can be one of the choices of learning models [2].

Several studies have been carried out regarding the implementation of inquiry in learning physics in schools. Students who through inquiry-based learning achieve higher scores than those through traditional methods [3]. Arslan applies open inquiry and guided inquiry to "pre-service" teachers and gets the results of some of the difficulties faced by teachers when implementing open inquiry. The difficulties that arise are (1) the absence of science process skills such as formulating hypotheses, research questions and defining variables (2) preservice teachers for the first time meeting with inquiry-based laboratories (3) when researching concepts and associating practicum they are with the work of scientists, they don't know where and how to start research. If an open inquiry is difficult to practice, then guided inquiry can be used as a transition [4]. Bilgin revealed that guided inquiry learning used in cooperative learning can make students develop concepts and positive attitudes [5]. In addition to all of the above, it should also be noted that the world is currently entering the era of the industrial revolution 4.0. or the fourth world industrial revolution where technology has become the basis of human life. Everything has become limitless due to the development of the internet and digital technology. This era has influenced many aspects of life both in the economic, political, cultural, artistic, and even to the world of education.

The relationship between education and the industrial revolution 4.0. is the world of education is required to have to follow the development of technology that is growing rapidly and use it as more and all-advanced facilities to facilitate the learning process. Also, it is hoped that the use of information and communication technology in learning mindsets can shift from teacher-centered to studentcentered. This is in line with the results of research which states that information and communication technology can improve the quality of education and as a support in the learning process. Technology must be as much a part of the classroom as other learning tools so that technology can act as a learning medium that helps teachers in learning activities. Learning media is a messenger technology that can be utilized for learning purposes. In addition to facilitating the teacher, instructional media also allows students to understand and comprehend something easier to remember it for a long time compared to the delivery of subject matter by way of lectures without assistive devices or learning media. There are so many media that can be used in learning, therefore any attempt to arrange the classification or classification according to the characteristics or characteristics is similar. Learning media, in general, are economized to be: (1) visual media, (2) audio media (listening media), (3) audio-visual media (hearing and listening media). This classification, which is suitable to be applied in learning activities for vocational students is audiovisual media. There are many advantages in the learning process that uses audiovisual media because the media can help students' understanding by seeing directly and can listen to explanations to be better understood by students. One of the audio visual-based learning media innovations that can be used is the Articulate Storyline.

Articulate Storyline is software that can be used to create interactive learning media with combined content of the text, images, graphics, sound, animation, and video [6]. The appearance of the work is similar to a powerpoint but is equipped with various optional features including characters, facial expressions, poses, and easy timeline settings, as well as music or video that can be edited directly on the timeline. This is supported by the results of previous research which states that the Articulate Storyline can have a significant impact on student learning outcomes and understanding of concepts [7]. The use of the Articulate Storyline media can increase student interest in learning so that an increase in learning achievement is obtained [8]. Based on these results, the use of the Articulate Storyline media in learning has a significant and effective impact in the learning process, so that students more easily understand the material being studied and can improve learning achievement. This is also quite supportive for Al-Amin Vocational School students who are indeed studying multimedia majors, where matters relating to information and communication technology will foster their learning motivation.

The provision of appropriate models and media are equally important in the implementation of the learning process. In the guided inquiry model seven phases must be carried out, namely presenting the problem, making a hypothesis, planning an investigation, carrying out an investigation, collecting data/information, making conclusions, and communicating. Media Articulate Storyline can be integrated into guided inquiry learning during the data collection phase and the communicating phase. Here Articulate Storyline can help students to 
make presentations, where data collected from the results of experiments and analysis of these data will be presented as attractive as possible in the Articulate Storyline media. With the use of media such as this, it is hoped that student's learning motivation will increase to study physics and presentations can be more interactive because if students feel happy and interested in learning the student's knowledge will be firmly embedded in memory and can improve student understanding and results in student learning achievement. Based on the explanation above, the researcher wants to conduct research development of guided inquiry learning model by articulate storyline media on elasticity material to increase student's motivation and learning achievement.

\subsection{General Background of Research}

\section{EXPERIMENTAL METHOD}

This research type is development research, researchers develop instrument that produce certain products that include syllabus, lesson plans, student activity sheets (student worksheets), student books, and knowledge learning test results.

\subsection{Sample of Research}

The subject of this research is the instructional guided inquiry learning model by articulate storyline media while the test subjects are 60 students divided into 2 classes, namely X MM 1 and X MM 2 at SMK Al-Amin Surabaya in Academic Year 2019/2020.

\subsection{Instrument and Procedures}

This research development of guided inquiry learning model by articulate storyline media was carried out through two stages, namely the development phase of the learning instruments and the testing phase of the learning instrument. A research instrument is a tool used to measure natural and social phenomena observed [9]. The research instruments developed to collect data in this study are as follows: (a) Learning Instrument Validation Sheet, (b) Learning Observation Sheet, (c) Student Activity Observation Sheet, (d) Test Sheet, (e) Skill Assessment Sheet, and (f) Student Learning Motivation Questionnaire Sheet.

\subsection{Data Analysis}

The data analysis techniques of the development and testing guided inquiry learning model by articulate storyline media to improve student learning achievement are as follows:

a. Analysis of the Validity of Learning Instrument

The data analysis techniques of the validation of learning instrument which include syllabus, lesson plans, student books, worksheets, and knowledge tests use qualitative descriptive. The data is obtained by using a learning instrument validation sheet and based on validator assessment which is then calculated the average score given. The average value of the validator score is used to determine the quality of the learning instrument [11].

Table 2.1. Learning Instrument Validation Criteria

\begin{tabular}{ccc}
\hline Interval Scores & Category Rating & Remarks \\
\hline $3,60 \leq$ score $\leq 4,00$ & Very valid & Can be used without revision \\
\hline $2,60 \leq$ score $\leq 3,59$ & Valid & Can be used with a little revision \\
\hline $1.60 \leq$ score $\leq 2.59$ & Less valid & Can be used with many revisions \\
\hline $1.00 \leq$ score $\leq 1.59$ & Invalid & Not yet usable and still requires consultation \\
\hline
\end{tabular}

The percentage of the suitability of the assessment of the two validators to the instructional development of guided inquiry learning model by articulate storyline media on elasticity material to increase student's motivation and learning achievement is based on interobserver agreement obtained from statistical analysis of the percentage of agreement [12]:

Information:

$$
R=\left[1-\left\{\frac{A-B}{A+B}\right\}\right] x 100 \%
$$

$\mathrm{R}=$ Percentage of agreement

$\mathrm{A}=$ Highest score from 2 evaluators

$\mathrm{B}=$ Lowest score from 2 evaluators

The instrument of appraisal is said to be reliable, if the reliability is $\geq 75 \%$.

b. Practical Analysis of Learning Instrument

The practicality of the learning kit in terms of three aspects, namely the implementation of the learning kit, the activities of students during the learning process and the obstacles during the learning process.

1) Analysis of the Implementation of Lesson Plan

The data analysis technique of the implementation of learning uses descriptive qualitative. The score given by the two observers when observing the implementation of learning is in the range of 1 to 4 ( $1=$ not good; $2=$ not good; $3=$ good; $4=$ very good). The criteria for the outcome of learning are determined by calculating the average number of assessment scores given by two observers with the criteria as shown in Table 2.2

Table 2.2. Learning Implementation Criteria

\begin{tabular}{cc}
\hline Interval Scores & Category Rating \\
\hline $3,60 \leq$ score $\leq 4,00$ & Very good \\
\hline $2,60 \leq$ score $\leq 3,59$ & Good \\
\hline $1.60 \leq$ score $\leq 2.59$ & Not good \\
\hline $1.00 \leq$ score $\leq 1.59$ & Very bad
\end{tabular}


Like the analysis of the validity of learning instrument, the analysis of the implementation of the lesson plan also calculates the percentage matching test from two observers to the implementation of the lesson plan obtained from the statistical analysis of the percentage of agreement:

Information:

$$
R=\left[1-\left\{\frac{A-B}{A+B}\right\}\right] x 100 \%
$$

$\mathrm{R}=$ Percentage of agreement

$\mathrm{A}=$ Highest score from 2 evaluators

$\mathrm{B}=$ Lowest score from 2 evaluators

2) Analysis of Student Activities

Analysis of student activities was carried out by two observers at each meeting. This assessment is carried out according to student activity observation sheets which are then analyzed in a quantitative description using the following percentage techniques:

Information:

$$
P=\frac{\Sigma A}{\Sigma N} \times 100 \%
$$

$\mathrm{P}=$ Percentage of student activity

$\Sigma \mathrm{A}=$ Number of students carrying out the activity

$\Sigma \mathrm{N}=$ Total number of students

3) Analysis of Obstacles During the Learning Process

Obstacle analysis is carried out by two observers during the learning process, written on the observation sheet of the learning process barriers for reflection on the learning process that has taken place and looking for a solution to improve the learning process at the next meeting.

c. Analysis of the effectiveness of learning instrument

The effectiveness of the learning instrument in terms of two aspects namely related to student motivation and student learning achievement after the learning process uses learning instrument that have been developed.

1) Analysis of Student Learning Motivation

Student learning motivation data obtained from student learning motivation questionnaires, then analyzed using qualitative descriptive. Analysis of student learning motivation questionnaire data using the Guttman scale. Students answer "Yes" is worth 1 and students answer "No" is worth 0 . Mathematically can be written as follows:

Information:

$$
P=\frac{\Sigma K}{\Sigma N} x 100 \%
$$

P: Percentage score of student learning motivation

$\sum \mathrm{K}$ : Number of students who chose the answer Yes or No

$\sum \mathrm{N}$ : Number of students who filled out the questionnaire

The percentage of student's learning motivation is converted with the following criteria [13]:

Table 2.3. Results of Student Learning Motivation Questionnaire Criteria

2) Analysis of learning achievement

\begin{tabular}{cc}
\hline Interval Scores & Category Rating \\
\hline $76 \%-100 \%$ & Very positive \\
\hline $51 \%-75 \%$ & Positive \\
\hline $26 \%-50 \%$ & Less Positive \\
\hline $0 \%-25 \%$ & Not Positive \\
\hline
\end{tabular}

Analysis of learning achievement is based on pretest and posttest learning outcomes data which are analyzed descriptively quantitative consisting of:

a) Complete learning indicators

Complete learning indicators can be calculated as a percentage using the following formula:

Information:

$$
\text { Completeness of learner indicators }=\frac{\Sigma \text { students who attained IP }}{\Sigma \text { students }} \times 100 \%
$$

IP = learning indicator

The learning indicator is said to be achieved if the percentage of mastery learning $\geq 70 \%$.

b) Individual completeness

This individual completeness is used for the assessment of knowledge competencies, skills competencies, and attitude competencies of each student. Students are said to be complete if the average value has reached the minimum completeness criteria (KKM). KKM on knowledge and skills competence that is equal to 2.66 with the title B-. while for KKM attitude is a good category. The following is the conversion of grades to fit the assessment model in the 2013 Curriculum.

c) Statistical Analysis

Statistical analysis was performed to determine an increase in student learning outcomes between before and after learning using learning tools that have been developed. Statistical analysis was performed using the average test of two samples with 
paired t-tests. The stages of this statistical analysis are described as follows:

- Normality Test

A normality test is a test to find out whether the data owned is normally distributed so that it can be used in parametric statistics. The method that can be used to conduct a normality test is to use the chi-square formulation as follows [14]:

Information :

$$
X^{2}=\sum_{i=1}^{k} \frac{\left(O_{i}-E_{i}\right)^{2}}{E_{i}}
$$

$\mathrm{O}_{\mathrm{i}}=$ frequency of observation

$\mathrm{E}_{\mathrm{i}}=$ expected / theoretical frequency

$\mathrm{k}=$ number of interval classes

A normality test is performed on each data sample that will be used (pretest and posttest). Samples can be said to be normally distributed if $X_{\text {hitung }}^{2}>X_{(1-\alpha)(k-1)}^{2}$ with a level of trust $(\alpha=0.05)$.

- $\quad$ Paired sample t-test

A paired sample t-test is used to compare the average of two variables in a single sample group and is used to test the hypothesis that there is no difference between the two variables [15]. The formulation to determine the value of $t$ is as follows:

Information:

$$
t_{\text {hitung }}=\frac{\bar{D}}{\left(\frac{S_{D}}{\sqrt{n}}\right)}
$$

$\mathrm{t}_{\text {arithmetic }}=\mathrm{T}$ value calculated

$\bar{D}=$ average value of $\mathrm{d}(\mathrm{x} 1-\mathrm{x} 2)$

$\mathrm{S}_{\mathrm{D}}$ : Standard deviation $\mathrm{d}$

$\mathrm{n}$ : the amount of data

In this study, the paired sample t-test used is the average similarity test of one party (left-hand side).

- One-party test

One-party tests conducted to determine whether or not there is an increase in student learning achievement before learning is done with student learning outcomes after learning by using the left side test. The formulation of the hypothesis for this two-part test is:

Information:

$$
\text { Ho: } \mu 1 \geq \mu 2 \quad \text { H1: } \mu 1<\mu 2
$$

$\mu 1=$ average pretest value

$\mu 2=$ average posttest value

The initial hypothesis $\left(\mathrm{H}_{0}\right)$ says that there is no increase in student learning achievement before given learning (pretest) with significant student learning achievement after learning (posttest). The alternative hypothesis $\left(\mathrm{H}_{1}\right)$ says that there is an increase in student learning outcomes before given learning (pretest) with significant student learning outcomes after learning (posttest). Test criteria are: Ho is accepted if tcount> with a real level $\alpha=0.05$. Data from the pre-test and posttest results were carried out by a qualitative descriptive analysis using N-Gain. N-Gain shows the magnitude of the increase in learning outcomes before and after treatment is given. According to Hake in Astuti (2014) Normalized score gain shows the level of effectiveness of the treatment on the acquisition of scores. N-Gain can be formulated as follows:

$$
N_{\text {Gain }}=\frac{\text { posttest score }- \text { pretest score }}{\text { maximum score }- \text { minimum score }}
$$

Table 2.4. Interpretation of Normalized Gain

\begin{tabular}{cc}
\hline Normalized Gain Value & Interpretation \\
\hline$-1.00<\mathrm{g}<0.00$ & There was a decrease \\
\hline $\mathrm{g}=0.00$ & There was no increase \\
\hline $0.00<\mathrm{g}<0.30$ & Low \\
\hline $0.30 \leq \mathrm{g}<0.70$ & Medium \\
\hline $0.70 \leq \mathrm{g} 1.00$ & Height \\
\hline
\end{tabular}

- $\quad$ Sensitivity Index

The sensitivity index of an item is a measure of how well the item can distinguish students who have received learning from students who have not received learning. An effective sensitivity index between 0.00-1.00 and closer to 1.00 indicates the sensitivity of items with greater learning effects. The item is said to be sensitive if the sensitivity of each item $\geq 0.30$ (Astuti, 2014). The formula used to determine the sensitivity index is:

Information:

$$
S=\frac{R_{A}-R_{B}}{T}
$$

$\mathrm{S}=$ item sensitivity index 
$\mathrm{T}=$ Number of students taking the test

$\mathrm{R}_{\mathrm{A}}=$ number of students who answered correctly on the final test

$\mathrm{R}_{\mathrm{B}}=$ number of students who answered correctly on the initial test

\section{RESULT AND DISCUSSION}

This research is a research development of guided inquiry learning model by articulate storyline media on elasticity material to increase student's motivation and learning achievement. Three criteria that need to be considered in assessing a product of research development are validity, practicality, and effectiveness. The learning instruments developed is a guided inquiry learning model by articulate storyline media. This learning instruments are used in vocational physics subjects on elasticity material. The process of designing this learning instruments is passed in two stages, the first is the feasibility test conducted by the validator and second, it makes improvements by the recommendations of the validator. The results of the validator assessment of the syllabus developed was valid with an average score of 3.46 and the percentage of matched assessment of the two validators was $98.29 \%$. There are several aspects assessed in the development of this syllabus, including: syllabus identity, indicators, learning materials, learning activities, assessment, time allocation, and learning resources. The developed lesson plan is then validated by 2 validators. The aspects assessed by the validator include the formulation of learning objectives, learning activities, and language. The results of the RPP validation show that the RPP that was developed was valid with an average score of 3.43 and the percentage of matched assessment of the 2 validators was $94.49 \%$. Based on the results of the assessment it is known that the lesson plans developed can be used in learning activities. The results of the validation of student books show that the developed student book has a valid category with an average score of 3.32 and the percentage of appraisal matches of the 2 validators is $95.6 \%$. The worksheet developed by the researcher is said to have a valid category with an average score of 3.47 and the percentage of matched assessment of the two validators is $97.28 \%$. Although valid in the category, the worksheet that was developed can only be used after it has been improved according to what is suggested by the validator. After repairs, the worksheets developed are suitable for use in learning activities. The results of this knowledge test gets a score above 2.6 so that the overall average score is 3.34 and the percentage of match matching of the 2 validators is $96.3 \%$. Therefore, all items developed by researchers can be said to be valid and can be used in research. Nevertheless, some problems need to be improved according to the suggestions of the validator. Some suggestions given are adding the number of questions to the analyzing indicator, equating the terms in writing questions with those in student books, drawing spring using real spring rather than resistor form. After the improvement is made, the developed knowledge test is appropriate to be used to measure student learning outcomes before and after following the learning process by using tools that have been developed by researchers.

The practicality of the learning instruments developed was reviewed based on 3 conditions, namely the implementation of the learning plan, the activities of students during the learning process, and obstacles during the learning process. The implementation of learning is obtained from observations made by two observers according to the activity in the compiled lesson plan. The aspects observed as a whole consisted of initial activities, core activities, final activities, time allocation, and the atmosphere of teaching and learning activities. The RPP in this study uses the inquiry learning model. The application of inquiry learning models has learning phases integrated into the core activities of the learning process. Overall the value of observations made by observers during two meetings in class X-MM 1 was found that each aspect received an average score of $\geq 3.0$ in the good category. In class X-MM 1 the average score obtained was 3.56 with a percentage of agreement of $96.39 \%$. This means that in class X-MM 1 the learning implementation plan developed is already quite practical. While in class X-MM 2 the average score obtained was 3.49 with a percentage of agreement of $97.6 \%$. This result also shows that the learning implementation plan developed at the second meeting was quite practical and positive student activities in both classes increased at the second meeting. In class X-MM 1 the most activity carried out was activity code G, which is making media, at meeting 1 this activity was carried out as much as $80 \%$ of the number of students, whereas at meeting 2 it increased to $93 \%$ of the number of students. This also applies when observations are made in class X-MM 2, where the activity that is mostly done is the activity of making media. At meeting 1 this activity was carried out as much as $75 \%$ of the total number of students, while at meeting 2 it increased to $90 \%$ of the number of students.

The effectiveness of learning can be known by observing student learning motivation questionnaire data and student learning achievement data. The first discussion is about the results of student learning motivation questionnaire data.each statement experienced a percentage increase after learning with the guided inquiry learning model by articulate storyline media on elasticity material. In class XMM 1 before getting treatment the results of the questionnaire got an average percentage of $12.67 \%$, then after treatment received an average percentage of $89.33 \%$. This means that an increase in learning motivation by $76.66 \%$. In class X-MM 2 before getting treatment the results of the questionnaire got an average percentage of $14.33 \%$, then after treatment received an average percentage of $81.90 \%$. This means that an increase in learning motivation by $67.57 \%$. Improved student learning achievement as seen from the pretest and posttest scores were analyzed using a two-party t-test and one-party t-test, which resulted in a tcount of 28.5527. While the table for the one-party test is 1.7613 and the table for the two-party test is 2.1447 . This shows tcount> ttable which means that the application of guided inquiry learning model assisted by Articulate Storyline media can provide a significant difference between student pretest and posttest results. In addition to the results of the t-test, $\mathrm{N}$-gain was also calculated to find out how much the increase in learning outcomes before learning (pretest) and after learning (posttest). Normalized score gain indicates the level of effectiveness of the treatment on the acquisition of scores. It can be seen that the value of N-Gain in the high category numbered 46 students from the total number of students of 60 . While the N-Gain in the medium category numbered 13 students and the N-Gain in the low category numbered 1 person. The high number of $\mathrm{N}$ Gain categories indicates that the learning process carried out has a significant impact on the mastery of student's knowledge before and after receiving learning using instructional learning instrument Articulate Storyline media. The results of the overall attitude assessment of students get the title "B" and "SB", for the percentage of the implementation of this attitude also > 70\%, this provides information that the attitude competency in guided inquiry learning model by articulate storyline media has been completed for all students. From the

http://dx.doi.org/10.29322/IJSRP.9.12.2019.p9648 www.ijsrp.org 
description above, it can be said that this learning instrument is effective enough to improve student learning outcomes in knowledge competencies, skills, and attitudes.

\section{CONCLUSION}

Based on the research results of the development phase and the trial phase II that has been carried out on 60 students of X-MM class of SMK Al-Amin Surabaya it can be concluded that: (a) Guided inquiry learning model by articulate storyline media on elasticity material consisting of syllabus, lesson plans, student worksheets, student books, and knowledge test sheets have met the validity requirements of a learning instruments. (b) Guided inquiry learning model by articulate storyline media on elasticity material that has been developed otherwise practical. This is seen from the implementation of learning that gets an average of $>3.00$, positive student activity increases at the next meeting, and obstacles that occur during the learning process can find alternative solutions so that learning objectives are still achieved. (c) The instructional guided inquiry learning model by articulate storyline media on elasticity material is declared effective. This is observed from the increase in student learning achievement after learning using the developed learning instrument, in addition to that student motivation also increases. Based on the conclusions above, it can be concluded that in general the development of guided inquiry learning model by articulate storyline media on elasticity material to increase student's motivation and learning achievement.

\section{ACKNOWLEDGMENT}

Authors wishing to acknowledge assistance or encouragement from supervisor, colleagues and Acknowledgments section immediately following the last numbered section of the paper.

\section{REFERENCES}

[1] Ergul A \& Afolabi F 2011 Contructivist practices through guided discovery approach: The effect on Students' cognitive achievement in Nigerian Senior secondary school physics Eurasian J Phys Chem. Educ: (Online) 16-25

[2] Kuhlthau C C Maniotes L.K \& Caspari A K 2007 Guided Inquiry Learning In The 21 st century USA: Libraries Unlimited

[3] Abdi A 2014 The Effect Of Inquiry-Based Learning Method On Students' Academic Achievement In Science Course Universal Journal of Educational Research 37 41 DOI: $10.13189 /$ ujer.2014.020104

[4] Arslan A 2014 Transition between open and guided inquiry instruction Procedia - Social and Behavioral Sciences 407-412

[5] Bilgin I 2009 The Effects Of Guided Inquiry Instruction Incorporating A Cooperative Learning Approach On University Students' Achievement Of Acid And Bases Concepts And Attitude Toward Guided Inquiry Instruction Scientific Research and Essay Academic Journals 1038-1046

[6] Darmawan D 2011 Bahan Ajar: Mengembangkan Model Pembelajaran Multimedia Interaktif Garut: STKIP

[7] Jannah N 2015 Pengaruh Penggunaan Multimedia Articulate Storyline dalam Meningkatkan Hasil Pembelajaran di Madrasah Aliyah Negeri 3 Kediri Tesis Tidak dipublikasikan Malang: Pascasarjana Universitas Islam Negeri Maulana Malik Ibrahim

[8] Setiawan D 2015 Inovasi Media Pembelajaran IPA Berbasis Animasi dan Articulate Storyline untuk Meningkatkan Minat Belajar Siswa UKSW Vol 3 No 2 Agustus 2015

[9] Sugiyono 2014 Metode penelitian kombinasi (mixed methods) Bandung: Alfabeta

[10] Arikunto S 2005 Prosedur Penelitian Suatu Pendekatan Praktek Jakarta: Rineka Cipta

[11] Ratumanan T G \& Laurens T 2011 Penilaian Hasil Belajar pada Tingkat Satuan Pendidikan Surabaya: Unesa University Press

[12] Borich G D 1994 Observation Skill for Effective Teaching New York: Mac Millian Publishing Company

[13] Riduwan 2010 Skala Pengukuran Variabel-Variabel Penelitian Bandung: Alfabeta

[14] Sudjana N 2005 Dasar-Dasar Proses Belajar Mengajar Jakarta: Sinar Baru Algersindo

[15] Furqon 2011 Statistika Terapan Untuk Penelitian Bandung: Alfabeta

\section{AUTHORS}

First Author - Mas'adah, M.Pd., Postgraduate Study of Science Education, Postgraduate, State University of Surabaya, Indonesia, and masadah.c@gmail.com

Second Author - Prof. Dr. Wasis, M.Si., Postgraduate Study of Science Education, Postgraduate, State University of Surabaya, Indonesia Third Author - Tjipto Prastowo, Ph.D., Postgraduate Study of Science Education, Postgraduate, State University of Surabaya, Indonesia. 